\title{
Semantic characterization of terms as a trace of terminological dependency ${ }^{1}$
}

\author{
Miguel Sánchez Ibáñez and J oaquín García Palacios
}

\begin{abstract}
Over the past decades, English has become a privileged language for the transfer of specialized knowledge, something which conditions the creation of new lexical units in other codes. This conditioning can result in what is called terminological dependency, a linguistic phenomenon which arises from a unidirectional transfer of specialized denominations between two different languages. Terminological neology in potentially depending codes such as Spanish reflects the way the importation of units from English implies a set of linguistic asymmetries with consequences in the conceptual configuration of specialized domains by the importing community of scientists. In this article, we propose a three-step analysis in order to detect and measure the terminological dependency of Spanish upon English in the domain of Alzheimer's Disease, based on the semantic characterization of a set of specialized neologisms related to this domain. After having analysed the semantic features of this group of units in English we have found that there exists a significant, though not exact, correlation between the uniformity of some semantic aspects and the degree of terminological dependency observed in their different equivalences found in Spanish.
\end{abstract}

Keywords: terminology, terminological dependency, semantics, neology

\section{Introduction}

The study of a language's lexical updating and, thus, of the neologisms created within its specialized languages - neonyms, according to Rondeau's denomination (1981) - cannot be carried out properly without bearing in mind the undeniable linguistic fact that not all the languages of human communication have the same prevalence (De Swaan, 2001; Gradol, 2006; Loubier, 2008). The supremacy of English, which has become a lingua franca for scientific communication in most specialized domains, compels researchers to study the terminology and terminological neology in Spanish and in other romance languages taking into account the relations of these codes with English.

In this scenario, the concept of terminological dependency (Humbley and García Palacios, 2012) takes on a special significance. This does not imply the refusal of the potential positive influence that a dominating language may have as a "fertilizing" element (Algardy et al., 1987). However, the concept of terminological dependency emphasizes the relevance of the asymmetry established between two linguistic systems in the frame of a specialized communication, where many of the parties involved usually tend to accept the situation in a self-indulgent, non-critical way (Hagège, 2013). 
We take this conception of terminological dependency as a starting point for this article. Our proposal is theoretically based on a series of terminological studies carried out over the past twenty years, which have led the discipline to an indisputable openness to new horizons which are both different but somehow complementary for the study of specialized communication. Some of these studies clearly stand out, such as the Communicative Theory proposed by Cabré (1999), which takes into account the dynamic, multipurpose dimension of terms, the cognitive approach specially pointed out in the works by Temmerman (2000) and, more recently, the semantically-oriented approach proposed in works by Faber (2012). Besides these approaches, we cannot neglect other milestones in the study of specialized languages which have emerged from the francophone context (Gaudin, 1993; Béjoint and Thoiron, 2000) and we must also mention those who have promoted an approach to the study of terminological neology, such L. Guilbert (1975), A. Rey (1976) and J.C. Sager (1990).

In addition, and as is usually done in current linguistic studies since the first works of J.M. Sinclair (1987, 1991), it is necessary to study the phenomenon in accordance with the real use of the terms, which can be observed after having established a corpus able to represent the state of the language we want to describe. In consequence, and as we will see below, our first step was to compile a set of texts in order to create two corpora, one in English and another in Spanish.

\section{Framework and methodology: traces of terminological dependency}

The analysis of the semantic characterization as a trace of terminological dependency which is presented in this article was carried out within the frame of a larger study ${ }^{2}$ whose aim was to propose a set of parameters for the analysis of the asymmetric transfer of specialized knowledge. The methodology followed in that study was divided into four parts:

- Corpus configuration: we created a specialized corpus related to Alzheimer's Disease, composed of texts published between 2000 and 2010. The corpus was divided into two subcorpora: one made up of texts written in English (which were academic articles titles and abstracts indexed in Medline) and another made up of texts written in Spanish, in this case, scientific articles published by the Spanish journal Revista de Neurología ${ }^{3}$. In total, we compiled 3218 pairs of titles and abstracts in English, composed by 620,513 words and 196 scientific articles in Spanish, which contained up to $1,114,678$ words.

- Detection of novel units in the English subcorpus: The detection of new terms in the English subcorpus was marked by several premises: first, their novelty under a formal point of view, second, their thematic relevance within the chosen domain and thirdly, their degree of implementation in the subcorpus. In order to follow these guidelines, we started by applying a lexicographic filter, and that way we selected all the units appearing in the subcorpus which were not recognized by an automatic lemmatizer ${ }^{1}$. After that, we took into account the chronological factor and organized all the selected terms depending on their year of first appearance in the subcoprus, from 2000 to 2010.

\footnotetext{
1 http://www.cis.uni-muenchen.de/ schmid/tools/TreeTagger/
} 
We then did two chronological contrasts in order to detect which units were actually new. The first contrast gave us a group of candidates appearing in 2010 which did not appear before in the subcorpus. However, we noticed that a lot of these units could easily be mere one-time lexical occurrences and, consequently, were not relevant at all for our purpose of analysing the terminological dependency. That was the reason why we decided to do a second chronological contrast which was, in this case, double: it was not just about detecting units not appearing in the previous years but finding those which, besides fulfilling that condition, did appear also at least once in the following years. That way we inserted a new element in our analysis: the terminological implementation. We finally selected all the units appearing in abstracts and titles present in our subcorpus which had been written in 2005 and 2006 and did not appear in the previous years but did so at least once in the following ones. The decrease of units which could be interpreted as lexical occurrences confirmed that taking into account the terminological implementation in our study had been useful. Thanks to this process we defined a list of 81 units which gave us some pieces of relevant information for the subsequent phases of our analysis.

- Search for equivalents in the Spanish subcorpus and gradation of the resulting terminological dependency: we tracked the way the notions conveyed by the units detected in the English subcorpus were expressed in the Spanish subcorpus. Once done, we established a terminological dependency scale in order to classify the equivalences detected. For that purpose, we assumed that the presence of total equivalents in the Spanish subcorpus implied the ability of this langue to express those notions independently from English and, thus, we considered that their degree of dependency would be lower than that which could be implied in the cases where no equivalents were detected. Those two assumptions were taken as the two extremes of the mentioned scale; in other words, we established that, for our study, total equivalents implied absence of dependency, and absence of equivalents implied total dependency. The degree of dependency of the 81 pairs of equivalences was graded according to the variety of denominative solutions found between both subcorpus, and since the list of resultant pairs was totally varied and dissimilar, we were forced to make the concept of equivalence more flexible; we came across denominative linkages where the solution in Spanish was a mere defining explanation or it just referred partially to the unit detected in the English subcorpus. That is the reason why a lot of non-canonical, partial equivalences will be found along the study we present. They must not be taken as total equivalencies which could be found in a dictionary, but as denominative linkages between two codes asymmetrically disposed to refer to Alzheimer's disease.

- Search and definition of traces of terminological dependency: Once we had designed the scale of terminological dependency, we determined the relationships that could exist between the position of each equivalent on the scale and also determined a range of factors which, due to their decisive role for the creation and survival of specialized neologisms, could be considered as traces of terminological dependency.

We were able to define a trace of terminological dependency as any pattern or recurrence found in the transfer of specialized lexical units between two codes proving the dependence, asymmetry, or subordination of one of the codes upon the other. Five traces were analysed: formal dependency, terminological implementation, cognitive adequation, 
semantic characterization and translation strategies (Sánchez Ibáñez, 2013). In this article, we provide an in-depth discussion of the data and conclusions drawn from one of them: namely, semantic characterization. This parameter for the analysis of terminological dependency is revealed by ascertaining if there is any kind of correlation between the following two variables: first, the recurrent semantic patterns used to transfer different conceptual classes from English into Spanish, and second, the degree of terminological dependency of the equivalences established.

\section{The trace of semantic dependency: a three-step analysis proposal}

The aim of this paragraph is to discuss in depth the semantic characterization of the detected units and their equivalences in Spanish, in order to determine if there are changes in that characterization and if those changes somehow reveal any kind of terminological dependency. For that purpose, we have divided the study into three parts:

- Organization of conceptual classes

- Study of the semantic features of the units detected, according to Pustejovsky's Generative Lexicon Model.

- Analysis of the terminological dependency which can be implied from the data gathered.

\subsection{Organization of conceptual classes}

\subsubsection{Sager and Kageura's conceptual classification as a taxonomical reference}

Since Dahlberg (1978), who described the conceptual classes for the domain of documentary sciences, there have been numerous domains in which the description of the concepts and their relation underlying the lexical units has been conducted. There are some other relevant examples, even previous to Dahlberg's, such as those made in domains like Computational Linguistics, Cognitive Sciences or Artificial Intelligence ${ }^{4}$. Some other more current models are those developed by Temmerman (2000), based on the Sociocognitivist approach, as well as the ones collected by Temmerman and Van Campenhoudt in a monographic issue of Terminology (2011). Other relevant studies are those carried out by Faber and her research group (Faber et al. 2005, 2009, 2013), where the importance of dynamism in any categorizing process is taken into account. Last, but not least, we especially point out the model suggested by Sager (1980, 1990), which was developed later by Sager and Kageura (1995) and finally by Kageura alone (2002). This is the model we have adopted to organize the concepts transferred by the terms detected in our corpora. The model resulting from the work developed by these two authors fits our needs due to its systematicity and to the importance it gives to the stability of the conceptual classes over the variations which can be derived from the interconceptual relations, though these relations were not relevant for our study.

In addition, the model proposed by Sager and Kageura (which stems from Pugh, 1984) turns out to be comprehensive enough to be indistinctly applied to different specialized domains. Table 1 summarizes the kinds of conceptual classes defined by both authors. 
Table 1. Conceptual classes according to Sager (1990) and Kageura (2002)

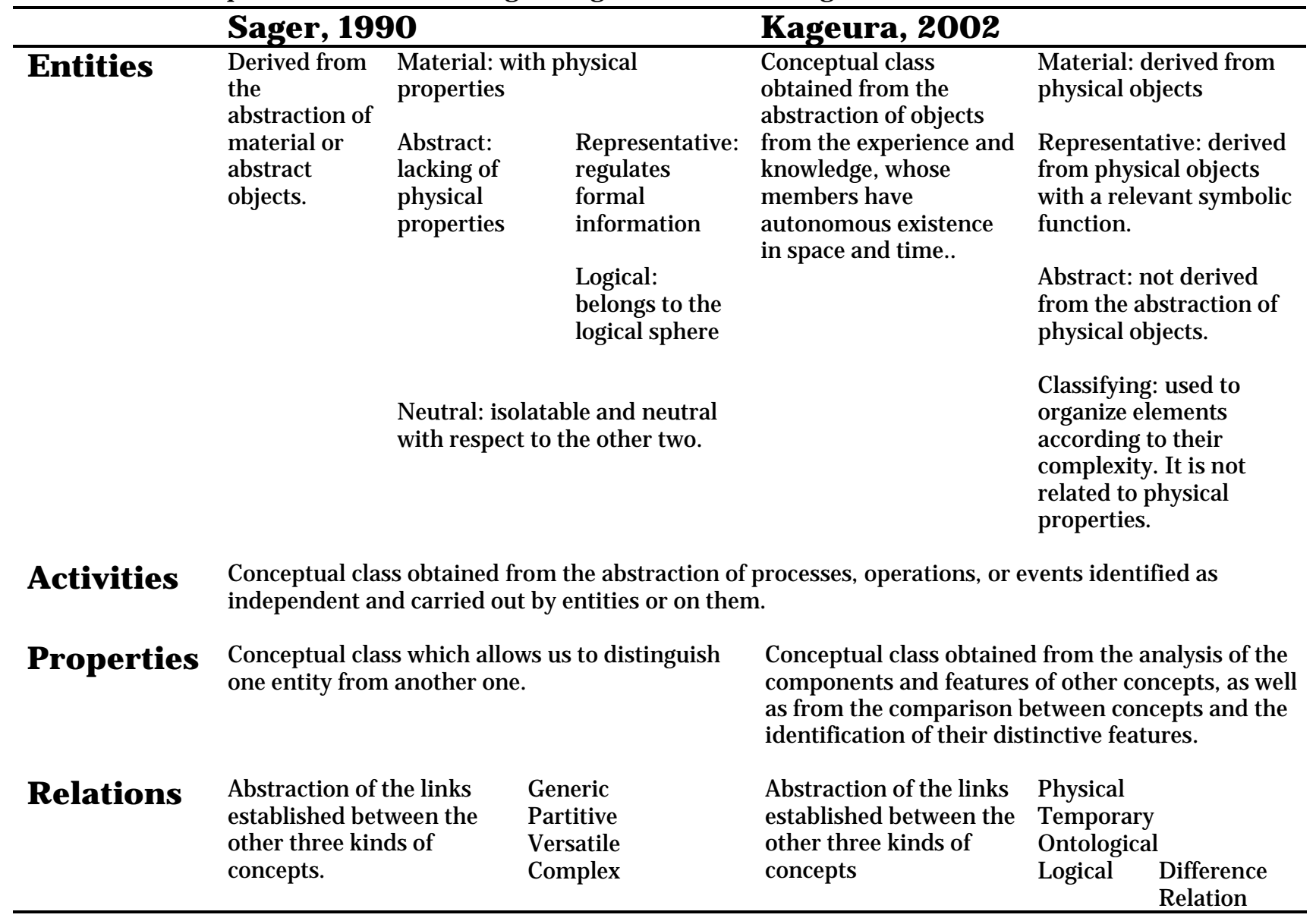

3.1.2 Application of Sager and Kageura's conceptual classes to the units detected in the English corpus

As we have already said, we based our classification on the one presented by these two authors in order to organize the units we found in our English corpus. For that purpose, we took into account the recurrences present in our compendium of new terms, trying to apply to them the schema proposed by Sager and Kageura. We classified our neologisms in two steps:

- First, we searched information regarding the notions underlying each unit: we looked all of them up in encyclopedic works, ontologies and manuals, basing our searches on the contexts offered by our corpus and on enquiries made to specialists. The goal was to clarify issues related to the domain which would allow us to better understand the concepts we were working with.

- Second, we assigned our units to the different conceptual classes. We divided the units and the multilexical terms with neological elements according to the conceptual classes they made reference to (see Table 2.), taking into account the classes defined by Sager and Kageura as the highest level of the classification. In the case of multilexical units, we have given priority to the conceptual class of the compound over that of new single elements. In other cases, we have added other units which often appear together with the units detected, in order to make them more understandable. 
The classification we propose in Table 2. has some specific features which make it singular: firstly, it is not a classification of all the concepts belonging to a domain, but of those relevant for the study we are carrying out; that is to say, concepts which are represented by the units we have found in our corpus. Secondly, there are more levels than in a regular established classification following the postulates of Sager and Kageura, because our goal is to puzzle out which conceptual classes in the domain of Alzheimer's Disease have novel denominations. Consequently, the goal of this classification is not to set a group of excessively general taxonomical bases, but to organize a group of concepts with very specific meanings, always bearing in mind that the information obtained is another factor which may be taken into account to measure the terminological dependency. In short, whereas our classification is not excessively exhaustive transversally (Fernández Silva, 2011: 138), since it is focused solely on what is relevant for our study, it does provide an in-depth inquiry into the concepts organized vertically (ibid.), in order to allow for the observation of as many semantic features as possible.

3.2 Study of the semantic features of the neologisms detected according to the generative Lexicon Model by Pustejovsky

The classification of the units detected, in accordance with the conceptual categories they referred to, allowed us to base their organization on premises which went beyond their formal structure and, consequently, opened a door for a new interpretation of the parcels of specialized reality they conveyed. However, we observed that the information given by this classification was insufficient. First, because in many cases we had simply isolated units whose analysis did not let us measure their terminological entity as autonomous units of signification. Second, because our classification had been based on definitions and on the senses given by the specific contexts where we had found them. Such an Aristotelian conception, which assumes that the meaning is but the addition of categories or notes which constitute a concept, limits the flexibility we consider necessary to better understand the semantic configuration of our units and to defend the inclusion of these units in a specialized domain as neological variable. If we had just accepted the application of the conceptual classes and we had not gone any further, it would have been impossible for us to understand till what extent the units we had found were novel or not within the domain of Alzheimer 's Disease. Besides, this limitation also prevented us from adopting conceptual relativism as a way to study terminological dependency. Our classification thus showed the semantic features of a group of neologisms in accordance with the singularities of their specific use in the contexts where they were found. Even if those singularities may finally refer us to the conceptual level, they are relevant enough by themselves to be considered the main references to track any traces of semantic dependency in our study

Having reached this point, we decided to turn to the Generative Lexicon Model suggested by Pustejovsky (1991, 1995, 1998), which was also developed by Adelstein and Kuguel (1999), Pustejovsky et al (2006) and Kuguel (2010), in order to conduct a comprehensive inquiry into the semantic characterization of our neologisms. This approach let us take a term's belonging to a specific domain as a neological variable which can behave as a context where concepts conveyed by the detected units are developed. In other words, as an environment which generates the new meaning for the units of our analysis. Their 
study according to the Generative Lexicon Model would let us analyze, first, the weight of the domain the units belong to as an aspect determining their degree of novelty, and second, the way semantic features were transferred from the units detected in English into the equivalences detected in Spanish.

Throughout the study, we have detected units which do not meet the traditional neology standards, because most of them are formally and semantically stable. We imply that their neological nature has been generated thanks to a set of external factors which were, somehow, related to the context. As Pustejovsky states: "the representation of the context of an utterance should be viewed as involving many different generative factors that account for the way that language users create and manipulate the context under constraints, in order to be understood." (1991: 2)

The Generative Lexicon Model allowed us to make one more step in the organization of conceptual classes, compared to the classification made under the Sager and Kageura Model. For this model, lexical units are defined as "metaentradas con múltiples sentidos en los que los distintos componentes del significado léxico se delimitan y relacionan entre sí mediante mecanismos generativos que operan al actualizarse el ítem léxico en un contexto determinado" (Kuguel 2010: 85), in accordance with our conceptions of belonging to a specific domain as a neological variable which acts as a context in which concepts conveyed by our detected units are generated and developed.

Pustejovsky (1991) considers that the semantic level of every lexical unit is made up of four elements or structures which give us four kinds of information:

- Argument structure: It is related to the functional level of the unit, to the information that can be implied from the way the unit interacts with other units. The analysis of the argument structure became especially relevant in our study, since it allowed us to find recurrent combinatory patterns in English, and determine whether those patterns were transferred into the equivalences found in the Spanish corpus. 
Table 2. Conceptual clases represented by the detected units

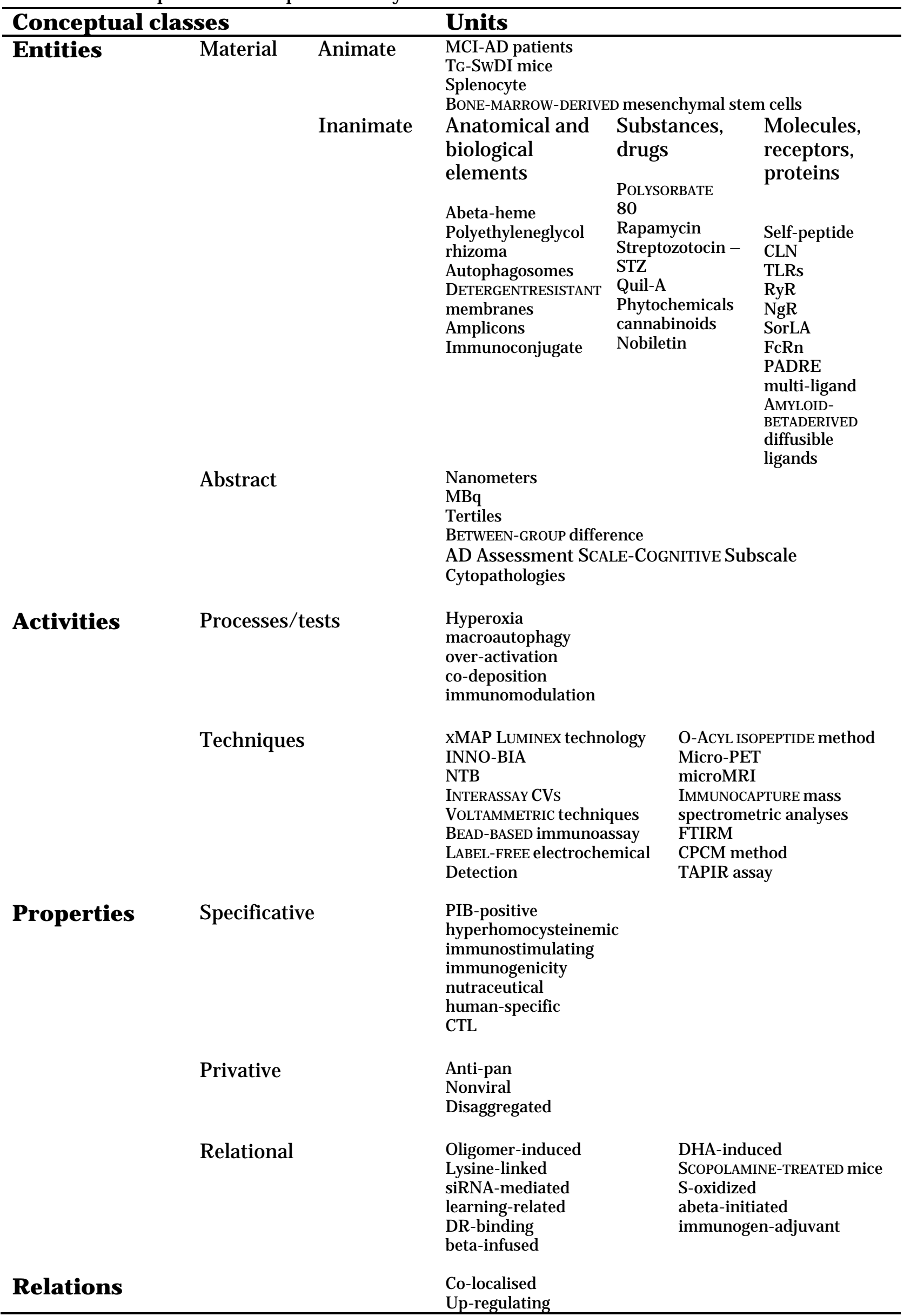


- Event structure: it informs about the kind of event to which the unit is linked. It can be temporary, spatial, or defined by contrasting the unit with others. This element tells us about the circumstances that play a role in the generation of the unit's meaning, which condition the way it is articulated with the conceptual classes represented by the units it shares context with.

- Qualia: they refer to the essential attributes of an object as it has been denominated by a lexical unit. In other words, it is the structure which gives us the information traditionally explained by classical definition templates, i.e. the group of notes and features which comprise the meaning of a lexical unit. They are especially taken into consideration by Faber et al. (2013) within their model of concept representation, since they are "directly related to our inventory of conceptual relations, and is extremely useful when it comes to writing semantic descriptions of words for large-scale systems" (2013: 182). In consequence, qualia become a versatile element for the study of semantics in terminology, because they are useful under a generative point of view, as in our analysis, but also if we adopt a cognitive approach: "Qualia afford a way of systematizing the description of previously conceptual systems. They can be used to systematically categorize the prototypical conceptual information or templates for conceptual description." (ibid.: 186).

- Inheritance: this element informs about the way a concept expressed thanks to the manner a lexical unit is conditioned by the relations with other concepts conveyed by other lexical units, either those which precede it or with which the unit has constant links (fixed inheritance), or those with wich it establishes extraordinary connections (projective inheritance).

The study of the recurrences or common patterns in the representation of all these structures and elements by the conceptual classes we have defined for the novel units we detected allows us to notice the conceptual implications that the lexical updating we have confirmed in the domain of the Alzheimer's disease can have. Besides that, it enables us to observe the way all these structures have been transferred into the equivalents found in the Spanish corpus.

Our goal was not to delve into the semantic characterization of each detected unit, but to focus on the most relevant features which may be useful for our study, which would be able to give information about the terminological dependency under a semantic point of view. That is why we have observed the way Pustejovsky's semantic structures are depicted in the selected contexts, assuming that the important thing for us was the semantic configuration of each unit as it was articulated in each of those contexts. That way, we have tried to avoid static definitions which, even if useful to understand the most common and accepted meaning of the collected units, did not fit the needs of our study.

In consequence, our analysis aims to contrast the two kinds of information defined and described in the two previous paragraphs: on the one hand, the concepts classified in Table 2. And on the other hand, the presence of Pustejovsky's four semantic structures (argument structure, event structure, qualia, and inheritance) in the terms which convey those concepts. If we found any kind of pattern in that contrast we would have the key to determine to what extent the semantic characterization of a set of terms and of their translations into other codes can be used to determine cases of terminological dependency.

In order to present our data in a more simple, clear way, we will explain just the 
cases in which the confluence of conceptual classes and semantic structures has allowed us to draw significant conclusions for our study. The specific cases which due to their representativity are developed in this article, are summarized in Table 3:

Table 3. Conceptual classes and Semantic structures analysed

3.2.1. Entities

3.2.1.1. Material inanimate entities

Argument structure

Event structure

Qualia

Inheritance

3.2.1.2. Abstract entities

Event structure

Inheritance

\subsubsection{Activities}

3.2.2.1. Processes/tests

Qualia

3.2.2.2 . Techniques

Argument structure

Event structure

Qualia
3.2.3. Properties

3.2.3.1. Specificative properties

Argument structure

Event structure

3.2.3.2. Privative properties

Inheritance

3.2.3.3. Relational properties

Event structure

Qualia

Inheritance

\subsubsection{Entities}

Within our group of neologisms, we established three kinds of entities: material animate entities, material inanimate entities and abstract entities.

\subsubsection{Material inanimate entities}

Material inanimate entities are one of the largest conceptual classes among the ones defined in our classification. We found references to anatomical and biological elements (autphagosomes, detergent-resistant membranes), to substances and drugs (polysorbate 80, rapamycin) or to different kinds of molecules, receptors and proteins (CLN, NgR).

Table 4. Kinds of Material inanimate entities

\begin{tabular}{lll}
\hline $\begin{array}{l}\text { Anatomical or biological } \\
\text { elements }\end{array}$ & $\begin{array}{l}\text { Substances, } \\
\text { drugs }\end{array}$ & $\begin{array}{l}\text { Molecules, } \\
\text { receptors, proteins }\end{array}$ \\
\hline Abeta-heme & POLYSORBATE80 & Self-peptide \\
Polyethyleneglycol & Rapamycin & CLN \\
rhizoma & Streptozotocin - STZ & TLRs \\
Autophagosomes & Quil-A & RyR \\
DETERGENTRESISTANT & Phytochemicals & NgR \\
membranes & cannabinoids & SorLA \\
Amplicons & Nobiletin & FCRn \\
Immunoconjugate & & PADRE \\
& & multi-ligand \\
& & AMYLOID-BETA DERIVED \\
& & ligands \\
\hline
\end{tabular}




\section{Argument structure}

If we focus on the way these units combine with others, we can describe the following patterns:

Molecules, receptors, proteins

In this case, the most relevant combinatory feature is that these units are very often inserted in contexts where prepositions indicate their situation in space with respect to other entities.

Table 5. Combinatory patterns. Material inanimate entities. Molecules, receptors, proteins

\begin{tabular}{lll}
\hline Entity 1 & Preposition & Entity 2 \\
\hline $\begin{array}{l}\text { CLN Could possibly play a role in } \\
\text { THE PREVENTION OF AD } \\
\text { PATHOGENESIS }\end{array}$ & THROUGH & $\begin{array}{l}\text { the inhibition of Fas-mediated } \\
\text { apoptosis }\end{array}$ \\
$\begin{array}{l}\text { Anti-Abeta antibody/Abeta } \\
\text { immune complexes are rapidly } \\
\text { cleared from brain to blood }\end{array}$ & VIA & $\begin{array}{l}\text { FCRN (neonatal Fc receptor) across } \\
\text { the BBB }\end{array}$ \\
\hline
\end{tabular}

\section{Substances, drugs}

The most recurrent structure in this case is the one which expresses that there is a study or research which proves that an entity in particular has a singular attribute, as we can see in the following table. In the same way, this combination is projected in the use of verbs such as play, enhance, describe or improve to insert those properties.

Table 6. Combinatory patterns. Material inanimate entities. Substances, drugs

\begin{tabular}{|c|c|c|}
\hline Study or research & Entity & Attribute \\
\hline We also provide evidence & $\begin{array}{l}\text { that intracellular CANNABINOID } \\
\text { type } 1 \text { receptors }\end{array}$ & play a role in stabilizing lysosomes \\
\hline $\begin{array}{l}\text { Our recent studies have } \\
\text { demonstrated }\end{array}$ & $\begin{array}{l}\text { that NOBILETIN, a } \\
\text { polymethoxylated flavone from } \\
\text { citrus peels, }\end{array}$ & enhances cAMP/protein kinase \\
\hline This paper describes & $\begin{array}{l}\text { a novel series of 18F-labeled } \\
\text { POLYETHYLENEGLYCOL (PEG)- } \\
\text { stilbene }\end{array}$ & $\begin{array}{l}\text { derivatives as potential beta- } \\
\text { amyloid }\end{array}$ \\
\hline $\begin{array}{l}\text { The results presented here(...) } \\
\text { show }\end{array}$ & $\begin{array}{l}\text { that RAPAMYCIN, an FDA } \\
\text { approved drug, }\end{array}$ & improves learning and memory \\
\hline These results suggest & $\begin{array}{l}\text { that switching from Alum to } \\
\text { QUIL-A }\end{array}$ & would be beneficial for $\mathrm{AD}$ patients \\
\hline
\end{tabular}

The high degree of terminological dependency detected in the equivalences found in the Spanish corpus for this kind of units impedes us from establishing any parallelism between both codes, although some attempts to reproduce the same kind of structures in Spanish can be glimpsed. For example, in the case of Nobiletin and the denominative periphrasis 
found in the Spanish corpus to express a very similar notion, we can see how the text in Spanish talks about the antioxidant property held by different kinds of nutrients, such as flavonoids (which the English context also talks about), but it does not name exactly Nobiletin as a kind of flavonoid. In both cases the location of the entity is relevant to explain its main features.

"Increasing evidence suggests that the elevation of beta-amyloid (Abeta) peptides in the brain is central to the pathogenesis of Alzheimer's disease $(\mathrm{AD})$. Our recent studies have demonstrated that NOBILETIN, A OLYMETHOXYLATED FLAVONE FROM CITRUS PEELS, enhances CAMP/protein kinase A/extracellular signal-regulated kinase/cAMP response element-binding protein signaling in cultured hippocampal neurons."

"Las células tienen SISTEMAS ANTIOXIDANTES. Estos sistemas pueden clasificarse en sistemas enzimáticos (...) antioxidantes endógenos (...) o contenidos en la dieta (las vitaminas Cy E, el ß- caroteno, los FLAVONOIDES, el selenio y el zinc)"

\section{Event structure}

The event these units are most often linked to is spatial, as is confirmed by the recurrence of prepositional structures we have already seen in Table 3. The spatial event is also expressed through the use of formants specifying the entity's position, or through the mere addition of extra information in the sentence, regarding this event. We can see that this event is also predominant in the Spanish examples. For instance, in the case of multiligand, it is easy to see that the three Spanish contexts that make reference to this notion also contain spatial information:

"Receptor for advanced glycation endproducts (RAGE), a member of the immunoglobulin superfamily, is a MULTI-LIGAND, CELL SURFACE RECEPTOR expressed by neurons, microglia(...)"

"EN CEREBROS CON EA se han encontrado niveles reducidos de la fracción asociada a membrana (presumiblemente activa)"

“(...) por su naturaleza de proteína MULTILIGANDO, actúe mediante diferentes mecanismos EN LOS DIFERENTES TEJ IDOS DONDE APARECE."

“La proteína precursora de amiloide (PPA) es una PROTEÍNA TRANSMEMBRANA, con una pequeña cola de carboxilo en el espacio INTRACELULAR, una sección intramembranosa y una porción EXTRACELULAR importante."

The following contexts where terms referring to material inanimate entities can be found (TLR and Rhizoma) also exemplify the relevance of the spatial event for the expression of these conceptual classes.

"Toll-like receptors (TLRS) are a family of pattern-recognition receptors in the innate immune system. EXOGENOUS AND ENDOGENOUS TLR ligands activate microglia” “(...) 
requires their retrograde transport TOWARDS THE NEURONAL CELL BODY, WHERE lysosomes are most concentrated."

“(...) a stilbene glucoside extracted FROM rhubarb roots (Rhei RHIZOMA).”

Qualia

Molecules, receptors, proteins

As we have already explained above, the relevance of these entities stems from their situation in space. However, we can also notice that the predominant qualia are the agentive $^{5}$ ones. In other words, we see that the specified qualities of these entities refer to their origin or family in order to place them in space.

“SELF-PEPTIDE (that is, a peptide PRODUCED BY THE ORGANISM ITSELF), such as Abeta," "Toll-like receptors (TLRS) ARE A FAMILY OF PATTERN-RECOGNITION RECEPTORS in the innate immune system."

“LR11 (also known as SorLA), A MEMBER OF THE LOW-DENSITY LIPOPROTEIN RECEPTOR FAMILY"

Inheritance

Anatomical or biological elements

Fixed inheritance appears clearly in the formal structures of the terms conveying these entities, and it helps place them in the conceptual tree of the domain, as we can see in examples such as autophagosomes, immunoconjugate or Rhei Rhizoma. At the same time, it eases the transfer of these units into other codes: the establishment of fixed models to formally express the links between different units within the same domain favors the formal uniformity in the transfers into other codes, something which makes the resulting terms more transparent. That is why, even if we have found neither autofagosoma, inmunoconjugado nor Rhei Rizoma in our Spanish corpus, we have no problem in suggesting, at least initially, those solutions as valid equivalents in Spanish for the mentioned units.

We observe that projective inheritances, that is to say, the punctual conceptual relations detected for this kind of units, are expressed through the use of hyphens (Abeta-heme, detergent-resistant. Besides that, it can be easily appreciated that the frequent use of this sign eases the lexicalization of units which apparently do not refer to just one conceptual class.

Molecules, receptors, proteins - Substances, drugs 
As happened in the previous case, fixed inheritances glimpsed in these conceptual classes let us see an attempt to build units taking into account other solutions to which they can be formally linked, as is the case for self-peptide. Apart from that, the variety of names of receptors detected (TLRs, RyR, NgR, FCRn), where the formal recurrence is systematic, let us imply that all of them convey concepts with similar features. And we find the same pattern in the case of substances and drugs, with examples such as Nobiletin, Rapamycin o Polysorbate. The equivalents found in the Spanish corpus made it possible to observe this pattern as well (Rapamicina, Polisorbato). In consequence, we prove that systematic naming of a set of entities belonging to the same category makes them, in the first place, more understandable and easier to be placed in the conceptual structure of the domain, and, in the second place, more likely to be successfully translated into other languages.

\subsubsection{Abstract entities}

Abstract entities found in the English corpus make reference to units of measure and gradation, with the exception of cytopathologies. They have been considered as entities and not as properties, in spite of their distinctive qualificative role, because they refer to abstract units of measure or analysis which just become properties once they are attached to quantifiers.

\footnotetext{
Nanometers

$\mathrm{MBq}$

Tertiles
}

BETWEEN-GROUP difference

AD Assessment SCALE-COGNITIVE Subscale Cytopathologies

\section{Event structure}

The main event linked to this kind of entities is the quantifier. All of them are inserted in events where the most important information regards numbers, indexes or proportions, although they are not quantifiers themselves. The equivalents found in the Spanish corpus preserve the specification of this event structure:

"The radiation burden of a SINGLE DOSE OF $300 \mathrm{MBq}$ (11) C-BTA-1 is within the accepted LIMITS for research purpose."

"Some biomarkers require FEWER patients to establish BETWEEN-GROUP differences than clinical assessment"

"Random effects regressions were used to examine the RELATIONSHIP AMONG CSF abnormalities, cognitive impairment (assessed with the ALZHEIMER DISEASE ASSESSMENT SCALE-COGNITIVE SUBSCALE [ADAS-COG]), and functional DECLINE (...)"

“(...) TRES O CUATRO horas después de la administración de 185 MBQ FP-CIT (ioflupano)"

"obtuvieron una MAYOR PUNTUACIÓN EN LA ESCALA de demencia de Blessed (diferencia INTERGRUPAL, P <0,01)."

"las variables principales fueron LA SUBESCALA COGNITIVA DE LA ESCALA DE VALORACIÓN DE LA ENFERMEDAD DE ALZHEIMER(...)."

Inheritance

Once again, we come up with contexts where the links between the conceptual classes 
studied and those which are close to them are sufficiently specified by the formal structure of their corresponding terms. Elements such as m-, nano- or between- help delimit the meaning of the units and, at the same time, confirm the links of the new entities they convey with those from which they arise (-Bq, -metre, -group). Projective inheritance shows us a set of established links between the studied units and other conceptual classes, such as properties (high, low, single, few) which confirm, once again, the importance of the quantifier element in the characterization of abstract entities. All these questions are preserved in the equivalences found in the Spanish corpus.

\subsubsection{Activities}

Detected units making reference to activities can be divided into two main groups: processes and/ or tests, and techniques.

\subsubsection{Processes and tests}

Processes and tests are the activities implying changes and transformations in the state and features of other conceptual classes, usually entities:

Hyperoxia

macroautophagy

over-activation

co-deposition

immunomodulation

Qualia

Whereas entities' qualia were mostly accesory and did not give much information, we have found a more significant presence of them in the case of processes, where they normally are telic, in other words, related to the aim or function pursued by each detected process. We also observe that there is a link between the expression of this kind of qualia and the insertion of the units conveying the expression in argument structures with a cause/ consequence meaning. We confirm that this link is quite well preserved in the transfer into Spanish of the units referring to this conceptual class.

\footnotetext{
“Macroautophagy, WHICH IS A LYSOSOMAL PATHWAY FOR THE TURNOVER OF ORGANELLES AND LONG-LIVED PROTEINS, (...)”

"Este último se internaliza rápidamente y se dirige al COMPARTIMENTO LISOSOMAL, donde experimenta una nueva DIGESTIÓN PROTEOLÍTICA, que interesa al extremo carboxilo del péptido beta y que termina con la formación de péptido beta libre [10]. Una vez formado EN EL COMPARTIMENTO LISOSOMAL, EL PÉPTIDO BETA SE ELIMINA a través del espacio extracelular y el líquido cefalorraquídeo [11-13], desde donde pasa rápidamente a la circulación sanguínea cerebral y sistémica [14]."
} 
"Exposure to HYPEROXIA for 5 days increased the number of cells with Abetacontaining lysosomes, as well as the number of apoptotic cells, compared to normoxic conditions."

"La expresión de la HO-1 SE PRODUCE COMO RESPUESTA a una gran variedad de estímulos prooxidantes, como (...) e HIPEROXIA"

\subsubsection{Techniques}

This category includes the activities related to analysis and methods, that is to say, activities closely linked to procedural aspects within the domain we are studying. It is a very large group where the presence of units such as method, assay, analyses or techniques helped us organize the concepts represented by the units detected.

XMAP LUMINEX technology

INNO-BIA

NTB

INTERASSAY CVS

VOLTAMMETRIC techniques

BEAD-BASED immunoassay
LABEL-FREE electrochemical detection

O-ACYL ISOPEPTIDE method

Micro-PET

microMRI

IMMUNOCAPTURE mass spectrometric analyses

FTIRM

CPCM method

TAPIR assay

\section{Argument structure}

According to the argument structures where these concepts are inserted, they have been given an active role with respect to other entities. Syntactically, this is reflected in their agent role in passive phrases, as we can see in Table 7.

Table 7. Combinatory Patterns. Activities. Techniques

\begin{tabular}{|c|c|c|}
\hline Patient subject & Verb & Agent \\
\hline Tau levels & Were analized & BY XMAP LUMINEX TECHNOLOGY \\
\hline $\begin{array}{l}\text { Antibody responders showed } \\
\text { improvements in cognitive } \\
\text { measures }\end{array}$ & As assessed & $\begin{array}{l}\text { By the neuropsychological test } \\
\text { battery (NTB) }\end{array}$ \\
\hline $\begin{array}{l}\text { (...) phtotriggered "click peptide" } \\
\text { isoform precursor isoform } \\
\text { precursors of Abeta 1-42 }\end{array}$ & Based on & The "O-ACYL-ISOPEPTIDE METHOD" \\
\hline The relative protein content & Was imaged & $\begin{array}{l}\text { With synchotron Fourier } \\
\text { transform infrared } \\
\text { microspectroscopy (FTIRM) }\end{array}$ \\
\hline The effects of solvation & Were accomodated & Using the CPCM METHOD \\
\hline
\end{tabular}

Likewise, some of their Spanish equivalences show a quite similar syntactic structure:

“con la nueva tecnología XMAP LUMINEX SE FACILITA el análisis, puesto que se pueden determinar los tres marcadores al mismo tiempo"

"Todos los pacientes FUERON ESTUDIADOS con una BATERÍA DE TESTS NEUROPSICOLÓGICOS”

“mediante LA ESPECTROMETRÍA DE MASAS, SE DETERMINÓ la secuencia de aminoácidos” 


\section{Event structure}

The main event in this case is the instrumental one, which fits the argument structures we have just seen: these conceptual classes are conveyed as tools for the development of the scientific dynamics, something proved in the English subcorpus by the use of the preposition by and the verb use, and derivative words of the latter, such as useful. Likewise, we find similar words and expressions in the Spanish subcorpus, such as mediante or a partir de:

\footnotetext{
"BY in vivo magnetic resonance microimaging (microMRI)"

"the relationship between $C$, Abeta and tau levels (..) were analyzed BY (...) xMAP Luminex technology"

"INNO-BIA plasma abeta forms MIGHT BE A USEFUL TOOL"

"we examined plasma samples (...) USING the tissue amyloid plaque imunoreactivity (TAPIR) assay."

"MEDIANTE la espectometría de masas(...)"

“(...) obtener la distribución de fuentes generadoras de corriente A PARTIR del voltaje medio"

"Ios valores de coherencia se calculan A PARTIR DE la aplicación de la transformada rápida de Fourier"
}

\section{Qualia}

The main semantic feature of these conceptual classes is the telic one, in part due to the predominance of the argument structures where these conceptual classes are presented as agentive subjects and also due to the instrumental event structures mentioned above. It seems as if these conceptual categories are transferred in specialized texts as activities leading to the achievement of a specific aim. This is proved by the use of expressions as as an [...] aim, in order to or to.

\footnotetext{
"AS A SECONDARY AIM, the rlationship between C, Abeta and tau levels (...) were analyzed by (...) xMAP Luminex technology."

"TO assess the development of beta-amyloid (...) by (...) (microMRI)"

"IN ORDER TO account for differences in density (...) the relative protein content ws imaged with synchotron Fourier transform infrared microspectroscopy (FTIRM)"
}

\subsubsection{Properties}

Properties are the third kind of conceptual classes detected in our corpus. We have divided them into three types, according to the contexts where they have been found, as well as to the kind of features they refer to: 


\subsubsection{Specificative}

These properties make reference to qualities without any prevailing semantic nuance, apart from the qualifying one.

PIB-positive hyperhomocysteinemic immunostimulating immunogenicity

\author{
nutraceutical \\ human-specific \\ CTL
}

\section{Argument Structure}

Due to their qualifying character, specificative properties have to be inserted into argument structures where they semantically complement other units. Consequently, most of them are conveyed by adjectives. Syntactically, this is reflected in the use of copulative clauses (as can be seen in the example of PiB-positive) and nominal phrases, as in the cases of nutraceutical, human-specific or CTL. The transfer of these noun phrases into Spanish is quite uniform, as we can see in the equivalences found for human-specific (específicamente humana) and for nutraceutical strategies (abordajes terapéuticos).

“MCI participants who were PIB-POSITIVE (...)”

"(...) toward prevention of Alzheimer disease-potential NUTRACEUTICAL STRATEGIES for suppressing the production of amyloid beta peptides."

“(..) we performed a histopathological analysis using mouse and HUMAN-SPECIFIC ANTIBODIES (...)"

"(...) we use mytochondrial transgenic cybrid models of sporadic $\mathrm{AD}(\mathrm{SAD})$, which overproduce Abeta compared to control (CTL) cybrids."

“(...) la enfermedad, por otra parte, más ESPECÍFICAMENTE HUMANA, la más propia del precio que paga nuestro cerebro por su evolución y por su longevidad.

"El control de estos mecanismos moleculares, integrados en la hipótesis de la denominada 'cascada amiloide' es, hoy por hoy, la diana de diferentes ABORDAJES TERAPÉUTICOS cuyo objetivo es restaurar el equilibrio de este sistema molecular"

\section{Event structure}

There is no clear event all these units make reference to, in contrast with what happens in other parts of the classification. The common ground for all of them is more abstract: we could say that all the units conveying these conceptual classes transfer information regarding a specific state. Secondarily, we can assume the presence of a process which favors the acquisition of that state. There are several examples in which these two event structures can be noticed. 
"The olfactory identification score did not differ between aMCI participants who were PIB-POSITIVE and those who were PiB-negative."

"No increases in beta secretase activity or evidence of neuronal cell loss in the HYPERHOMOCYSTEINEMIC mice were found."

"To improve the IMMUNOGENICITY and reduce the likelihood of inducing adverse autoreactive T-cells specific for Abeta42, we previously tested in wild-type mice an alternative approach for active immunization."

"(...) we performed a histopathological analysis, using mouse and HUMAN-SPECIFIC antibodies.”

Table 8. Patterns in the representation of the event structure. Specificative properties

\begin{tabular}{lll}
\hline State & Entity & Process \\
\hline PIB-POSITIVE & MCI participants & Olfactory identification score \\
HYPERHOMOCISTEINEMIC & Mice & Neuronal loss \\
IMMUNOGENICITY & Wild-type mice & An alernative approach for \\
& & active immunization \\
HUMAN-SPECIFIC & Antibodies & Histopathological analysis \\
\hline
\end{tabular}

\subsubsection{Privative properties}

These properties express qualities based on the negation or the assumption of the lack of some kind of feature or element.

Anti-pan

Nonviral

disaggregated

Inheritance

Fixed inheritance in the units conveying this kind of information marks their classification in an independent conceptual class, since the prefixes they present (anti-, non-, dis-) help place them in the conceptual domain via their contrast with other properties. However, the number of units presenting these singularities is very low, which makes us suspect that there are other ways to express this kind of information which are not based on the creation of new terms. Actually, if we check the equivalences found in the Spanish subcorpus, all we find is a denominative periphrasis for one of them (disaggregated), whereas there are no equivalences for the other two. The absence of clear terminological equivalences denotes the existence of a gap between both codes which has as an effect on the high degree of terminological dependency we find in this point of the classification.

“Using a novel method to present purified, DISAGGREGATED ABETA PEPTIDES to primary cortical neurons, the detailed temporal pattern of neurotoxicity was assessed."

"La vitamina $\mathrm{C}$ y la vitamina $\mathrm{E}$ se han propuesto como fármacos CON POTENCIALIDAD PARA REDUCIR LA AGREGACIÓN DEL PÉPTIDO AMILOIDE, de manera que pueden ejercer 


\title{
3.2.3.3 Relational properties
}

In this case, the main attribute specifies links, processes or other kind of relations between other conceptual classes, generally entities.

Oligomer-induced

Lysine-linked

siRNA-mediated

amyloid BETA-INFUSED rats

learning-related
DHA-induced

SCOPOLAMINE-TREATED mice

S-OXIDIZED radical cation

abeta-initiated

immunogen-adjuvant

\section{Event structure}

Different kinds of events can be noticed through the units conveying these concepts. In contrast with other conceptual classes, where the transfer of one event by all the units detected was quite clear, in this case the properties themselves are the event structure. We can see this in the following examples, many of which express cause events:

\begin{abstract}
“The role for cellular prion protein $\operatorname{PrP}(\mathrm{c})$ in beta-amyloid (Abeta) OLIGOMER-INDUCED SYNAPTIC IMPAIRMENT is a topic of great interest"

"Docosahexaenoic acid-induced protective effect against impaired learning in AMYLOID BETA-INFUSED RATS is associated with increased synaptosomal membrane fluidity."

"The present results indicate that DHA-INDUCED alterations in synaptic plasma membrane fluidity may contribute to the synaptic plasma membrane-related functions"

“(...) there is a causal relationship between cerebrovascular dysregulation and ABETAINITIATED pathology, and whether influencing targets in the neurovasculature(...)"

“Estudios EN RATAS QUE RECIBIERON INFUSIÓN ICV de NGF revelan una distribución rápida en el sistema ventricular y limitada penetración en el parénquima cerebral"

"Más aún, en la actualidad, la hipótesis de que la acumulación intracelular del BA podría desempeñar UN PAPEL PREDOMINANTE EN LA PATOLOGÍA DE LA EA reta la propuesta inicial de toxicidad extracelular del bA."
\end{abstract}

\section{Qualia}

There are two qualia shared by most of these properties: the agentive and the telic. As we have seen in the contexts exemplifying the event structure, the units expressing these conceptual classes are able to complement the meaning of processes or transformations, mainly marked by causes and effects, but also by time and space. Information regarding where they go to and where they come from thus conditions the semantic characterization of these units. This is reflected in the use of verbs as induce, result, involve, associate, contribute o influence, or in the Spanish implicar, inducir o relacionar. 
The information structured by these units is placed in the limit between what we can call fixed inheritance (the one revealed by the relations between a concept and its concepts of origin, or between two concepts with a constant connection) and projective (the one established exceptionally between two concepts in a context in particular). The clarity of the event structures and the qualia expressed by this kind of properties is a consequence of the constant use of some patterns and systemacity found in their formal structures, which are usually composed of a noun hyphenated to an adjectival participle. This thus reflects, thus, a transfer of semantic information halfway between the one-time and the lexicalized designation, as seen in the equivalences found in the Spanish subcorpus, which show a very low degree of terminological dependency but whose terminological character is not very clear (scopolamine-treated - tratados con escopolamina; learning-related - relacionado con el aprendizaje). There were no clear morphosyntactic patterns which could enable us to find a clear correlation between both factors ${ }^{6}$, but these units embody the most revealing sign of a link between formal structure and degree of dependency we found during the course of the whole study. As Sanz Vicente states, (2011: 595) regarding premodification as a morphological resource in English,

“El recurso a la premodificación en inglés, que tiene su explicación en la pérdida de flexiones que esta lengua ha sufrido a lo largo de su historia, permite sintetizar los sintagmas nominales y de esta forma comunicar más información con menos palabras, facilitando asimismo su lexicalización como unidades terminológicas e imprimiendo dinamismo a los textos especializados."

3.3 Analysis of the terminological dependency which can be implied from the data described above

The third step of our analysis is to compile all the data collected so far in order to determine to what extent and in which cases we can discern some kind of correlation between the two sets of elements we have previously explained in detail. These elements are, on the one hand, the semantic uniformity and the constant patterns used to represent the conceptual classes, and, on the other hand, the degree of terminological dependency of the pairs of equivalences established between the two codes used in this analysis.

\subsubsection{Argument structure}

We find some combinatory patterns which are reflected in recurrent syntactic structures; first of all, there is a variety of cases, along all the conceptual classes studied, whose syntactic structuring makes them patient subjects of an action expressed by a passive verb, whereas their translation into Spanish makes them become agentive elements of that same action, or results which emerge from the processes. We notice, nevertheless, that these syntactic changes are not the reflection of a significant transformation in the argument 
structure of the notions transferred, which is preserved without relevant modifications in most of the transfers studied.

\subsubsection{Event structure}

There are several events which can be easily assigned to some conceptual classes and are quite clearly expressed both in the solutions found in the English subcorpus and their Spanish equivalences.

- Quantifier event: it is the predominant event in the case of material animate entities and abstract entities. In the second case, it was almost totally preserved in the Spanish equivalences.

- Spatial event: once again, the entities are the concepts where this event prevails over the rest, although in this case we talk about the material inanimate entities. More specifically, the molecules, receptors and proteins were expressed in contexts linked to spatial events. Likewise, we observed that the transfer of this semantic information into Spanish was fairly constant.

- Causal event: this event was the most obvious in the case of material inanimate entities (mainly substances and drugs), as well as in the case of activities which constitute process and in relational properties. In all these cases, it is easy to notice the existence of similar event structures in the equivalences found in the Spanish subcorpus, regardless of the terminological character of the units which, in the case of the properties, was vaguer. We must point out as well the importance of the pattern estate-entity-process in the case of the specificative properties as main event structure.

\subsubsection{Qualia}

The main qualia detected in the analyzed units are the following ones:

- Agentive: features related to their origin and family were especially clear in the case of material inanimate entities (mainly molecules, receptors and proteins), as well as in the case of relational properties.

- Telic: the conceptual classes showing most clearly this kind of semantic information related to purpose and functionality were material inanimate entities (in particular, substances and drugs) and the activities, both the processes and the techniques. In all the cases it was clearly preserved in their transfer into the equivalences found in the Spanish subcorpus.

- Formal: this kind of features were the most important to define properties, although they were always subject to the entities whose meaning they complemented.

\subsubsection{Inheritance}

In this case, the results are not as clear as the ones explained so far, since its importance in the semantic configuration of the units detected is not very well proved, because there were 
not many concluding patterns. Yet, we believe there are some revealing data:

- Fixed inheritance: the systematicity in terms of the way the relationship between a group of concepts is proved, according to their formal representation, has shown us, throughout the whole analysis, that it is easier to find operational formal equivalences in other codes. We have found some clear examples, when talking about material inanimate entities (molecules, receptors and proteins, or substances and drugs, mainly) or techniques, where the formal gap between English and Spanish affords us a glimpse of some kind of dependence which is more related to the domain than to the specialized language itself.

- Projective inheritance: in the cases where conceptual links are not constant, the hyphen ${ }^{7}$ has been the most common formal resource found in the detected units. Besides, the equivalences found in Spanish did not show a clear formal pattern and revealed to what extent the formal resources held by a code can have an influence on the lexicalization and the implantation of a term. As we have mentioned before, the morphosyntactic structures of the detected terms did not turn out to be particularly important for the study of the degree of terminological dependency held by their Spanish equivalences, but we cannot ignore the relevance of the hyphen as a factor which favors lexicalization, something which is not preserved in the transfer into Spanish and results in a loss of semantic stability of the found equivalences.

Table 9 summarizes the most relevant and constant semantic features found in the units analyzed, in accordance with each on the four structures previously explained in detail:

Table 9. Summary of the most constant semantic features found the studied units

\begin{tabular}{|c|c|c|c|c|}
\hline & $\begin{array}{l}\text { Argument } \\
\text { structure }\end{array}$ & Event structure & Qualia & Inheritance \\
\hline Entities & $\begin{array}{l}\text { Pattern: } \\
\text { Study-entity-attribute }\end{array}$ & $\begin{array}{l}\text { Quantifier } \\
\text { Spatial } \\
\text { Causal }\end{array}$ & Agentive & $\begin{array}{l}\text { Fixed: } \\
\text { systematized } \\
\text { nomenclatures. }\end{array}$ \\
\hline Activities & $\begin{array}{l}\text { They are often syntactically } \\
\text { expressed by passive } \\
\text { clauses. }\end{array}$ & Instrumental & Telic & \\
\hline Properties & $\begin{array}{l}\text { Almost all of the units } \\
\text { conveying them make part } \\
\text { of nominal clauses. }\end{array}$ & $\begin{array}{l}\text { Causal } \\
\text { Pattern: } \\
\text { State-entity-process }\end{array}$ & $\begin{array}{l}\text { Agentive } \\
\text { Telic } \\
\text { Formal }\end{array}$ & $\begin{array}{l}\text { Projective: is } \\
\text { constant, } \\
\text { although the } \\
\text { transfer is not } \\
\text { uniform. }\end{array}$ \\
\hline
\end{tabular}

\section{Conclusions}

If we summarize all the data compiled throughout the present study, there seems to be a significant, though not exact, correlation between the uniformity of some semantic features comprising the different conceptual classes defined and the degree of terminological dependency detected in the equivalences found in Spanish. We confirm, for instance, that some of the activities and entities structured in the frame of the same event, or inserted in a 
syntactic structure following a similar pattern, present a lower degree of terminological dependency in Spanish than other conceptual classes, such as properties, where that uniformity is not so clear for some of their semantic features.

In consequence, we can conclude that, according to the signs we have observed and within the specialized domain of Alzheimer's Disease, a higher semantic uniformity of a set of units conveying the same kind of conceptual classes lowers the degree of terminological dependency of the equivalences for those units in another code. Semantic characterization of a group of terms, conceived as the group of elements which help generate their meaning, can have an influence on the way equivalents in other codes are established. In short, the semantic trace of terminological dependency becomes a relevant parameter to measure the linguistic gaps between two specialized languages within the same domain, but belonging to different linguistic codes.

\section{References}

Adelstein, Andreína, and Inés Kuguel. 1999. "La reducción de los sintagmas terminológicos". In Actas del I Seminario Terminología y Mercosur "Recursos léxicos para la terminología", 42-56. Buenos Aires: Universidad Nacional de General Sarmiento - Reunión Especializada de Ciencia y Tecnología, RECYT - Mercosur.

Algardy, Françoise. et al. (eds). "La fertilisation terminologique dans les langues romanes. Actes du colloque d'octobre 1986". Meta 32 (3), 1987: 217-370.

Dahlberg, Ingetraut. 1978. "A Referent-Oriented. Analytical Concept Theory for Interconcept". International Classification 5 : 142-151.

Faber, Pamela, Carlos Márquez Linares and Miguel Vega Expósito. 2005. "Framing Terminology: A Process-Oriented Approach". Meta 50 (4), 2005.

Faber, Pamela, Pilar León Araúz and Juan Antonio Prieto Velasco. 2009. "Semantic Relations, Dynamicity, and Terminological Knowledge Bases". Current Issues in Language Studies 1: 1-23.

Faber, Pamela (ed.) 2012. A Cognitive Linguistics View of Terminology and Specialized Language. Berlin/ Boston: Mouton de Gruyter.

Fernández Silva, Sabela. 2011. Variación terminológica y cognición. Factores cognitivos en la denominación del concepto especializado. Doctoral thesis. Barcelona: Institut Universitari de Lingüística Aplicada, Universitat Pompeu Fabra.

Gaudin, François. 2003. Socioterminologie: une approche sociolinguistique de la terminologie. Bruxelles: De Boek Duculot.

Guilbert, Louis. 1975. La créativitélexicale. Paris: Larousse.

Hagège, Claude. 2013. Contre la pensée unique. Paris: Odile J acob.

Humbley, John, and Joaquín García Palacios. 2012. "Neology and terminological dependency." Terminology 18 (1): 59-85.

Kageura, Kio. 2002. The dynamics of terminology: a descriptive theory of term formation and terminological growth. Amsterdam/Philadelphia: John Benjamins Publishing Company.

Kuguel, Inés. 2010. La semántica del texto especializado: los términos en textos de 
ecología. Doctoral thesis. Barcelona: Institut Universitari de Lingüística Aplicada, Universitat Pompeu Fabra.

Loubier, Christiane. 2008. Langues au pouvoir: politique et symbolique. Paris: L'Harmattan.

Masterman, Margaret. 1962. "Semantic message detection for machine translation, using an interlingua". In 1961 International Conference on Machine Translation of Languages and Applied Linguistic Analysis, 437-475. London: Her Majesty's Stationery Office.

Pugh, J. M. 1984. A contrastive Conceptual analysis and Classification of Complex Noun Terms in English, French and Spanish with Special Reference to the field of Data Processing. Manchester: University of Manchester.

Pustejovsky, James. 1991. "The Generative Lexicon". Computational Linguistics 17 (4): 409-441.

Pustejovsky, James. 1995. The Generative Lexicon. Cambridge: MIT Press.

Pustejovsky, J ames. 1998. "The semantics of lexical underspecification". Folia Linguistica 32 (3-4): 323-348.

Pustejovsky, J ames. 2001. “Type construction and the logic of concepts”. In P. Bouillon, and F. Busa (eds.), The Syntax of Word Meaning, Cambridge: Cambridge University Press.

Pustejovsky, James. 2005. A survey of dot objects. Available at: http:// www.cs.brandeis.edu/ -jamesp/ dots.pdf

Pustejovsky, James. et al. 2006. "Towards a generative lexical resource: The Brandeis semantic ontology". In Language Resources and Evaluation Conference, LREC 2006. Available at: http:// www.cs.brandeis.edu/ arum/ publications/lrec-bso.pdf

Rey, Alain. 1976, “Néologisme, un pseudo concept ? " Cahiers de Lexicologie 28, 1976, 3-17. Rondeau, Guy. 1981 [1984] Introduction à la terminologie. Chicoutimi: Gaëtan Morin éditeur

Sager, Juan C. 1980. English special languages. Principles and Practise in Science and Technology. Wiesbaden: Brandstetter Verlag.

Sager, Juan C. 1990. A practical course in terminology processing, Amsterdam/ Philadelphia : J ohn Benjamins Publishing Company.

Sager, Juan C. and Kio Kageura. 1995. "Concept classes and conceptual structures. Their role and necessity in terminology". In Symposium on French language and linguistics, ALFA, 191-216.

Sánchez Ibáñez, Miguel. 2013. Neología y traducción especializada: claves para calibrar la dependencia terminológica español-inglés en el ámbito de la Enfermedad de Alzheimer. Doctoral thesis. Salamanca: Universidad de Salamanca.

Sanz Vicente, María Lara. 2011. Análisis contrastivo de la terminología de la teledetección. Doctoral thesis. Salamanca: Universidad de Salamanca.

Sinclair, J ohn McHardy. 1987. Looking Up: an Account of the COBUILD Project in Lexical Computing. London: Collins.

Sinclair, John McHardy. 1991. Corpus, Concordance, Collocation. Oxford: Oxford University Press.

De Swaan, Abram. 2001. Words of the world. The global language system. Cambridge: Policy Press.

Temmerman, Rita. 2000. Towards new ways of terminology description: the sociocognitive-approach. Amsterdam/Philadelphia: John Benjamins Publishing Company. 
Temmerman, Rita and Marc Van Campenhoudt. 2011. "The dinamics of terms in specialized communication: An interdisciplinary perspective". Terminology 17 (1), 1-8.

\section{Authors' addresses}

Miguel Sánchez Ibáñez

West Virginia University

Department of World Languages,

Literatures and Linguistics

Office 301, Chitwood Hall

26501, Morgantown, West Virginia (USA)

misanchezibanez@mix.wvu.edu

miguelsanchez@usal.es
J oaquín García Palacios

University of Salamanca

Department of Translation and

Interpreting

Francisco de Vitoria, 6-16

37008 Salamanca (Spain)

gpalacios@usal.es

\section{About the authors}

Miguel Sánchez Ibáñez holds a $\mathrm{PhD}$ in Translation and Intercultural Mediation from the University of Salamanca. He is currently working as a Spanish instructor at West Virginia University, and he is a researcher at the group NeoUSAL. He has done a research stay in the Department of Translation and Linguistics at the Université de Montréal (Quebec, Canada) under the supervision of Professor Sylvie Vandaele. His research interests are terminology, neology, sociolinguistics and Spanish as a foreign language.

Joaquín García Palacios is full professor at the Department of Translation and Interpreting at the University of Salamanca, where he lectures in terminology. He is interested in the study of the Spanish vocabulary and he is currently coordinating two research projects, one regarding terminological neology in the domain of Neurosciences and another regarding the study of the neology in the press.

\section{Acknowledgements}

We would like to thank Dr. Daniel Linder, professor at the University of Salamanca, for his help and advice during the preparation of this article.

\section{Notes}

1.This article was written within the framework of the following research projects: Regulación de los procesos neológicos y los neologismos en las áreas de Neurociencias (ref. FFI2012-34596), funded by the Spanish Ministry of Economy, and Mecanismos de generación neológica y actualización léxica del español a través del estudio de la prensa castellanoleonesa (Neousal II) (Ref. SA-274U13), funded by the regional government of Castile and Leon.

2. «Neología y traducción especializada: claves para calibrar la dependencia terminológica español-inglés en el ámbito de la Enfermedad de Alzheimer» (Neology and specialized translation: some keys to determine the terminological dependency of Spanish upon English in the field of the Alzheimer's Disease (Sánchez Ibáñez, 2013).

3. As we have mentioned above, we chose a selection of papers on Alzheimers' disease indexed by Medline (http://www.ncbi.nlm.nih.gov/pubmed) between 2000 and 2010. We chose those which were indexed under the keywords “Alzheimer disease” and "amyloid beta - peptides” after having observed a clear increase of papers published under this indexation in this database for the chosen period. Regarding the Spanish subcorpus, we chose the Revista de 
Neurología (www.revneurol.com). In this journal, all the papers are indexed according to a range of thematic areas established by the editors. Each one of those areas is a subdomain within Neurology and one paper can be indexed under more than one subdomain. The fact that "Enfermedad de Alzheimer" was not a subdomain itself made us rethink our search criterium and we finally decided to choose every paper indexed for the subdomain "Neurodegeneración” and published between 2000 and 2010. After this first sifting we noticed that a lot of the selected papers were not related to Alzheimers' Disease, so we decided to apply a second filter: among all the papers indexed under the "Neurodegeneración” tag, we selected only those which had "Enfermedad de Alzheimer” as a keyword.

4. For further data, see proposals by Masterman (1962) or Schank (1976, in Kageura, 2002).

5. Pustejovsky (2006) defines this kind of quale as "the factor involved in the object's origins or "coming into being”" . According to Kuguel, (2010: 87) "el agentivo identifica un conjunto de eventos individuales involucrados en el origen o la causa del objeto". Faber et al (2013: 195) state the importance of the agentive role "since any event can be the result or the cause of another event or entity".

6. As stated in the larger study where other traces of terminological dependency were analyzed, (Sánchez Ibáñez, 2013: 330) "La falta de una correlación lógica entre estructura formal y grado de dependencia terminológica nos hace pensar que esta marca, no aporta una información decisiva”.

7. It is important to point out that the detection of novel units was focused on monolexical units or on those without any kind of space among their characters. That is why some hyphened multilexical units were selected as well and, in consequence, this diacritic sign gains importance in this phase of the study. 